\title{
Assessment of Air Pollution in Public Health and Socioeconomic Situation in Chabahil, Kathmandu Metropolitan City, Nepal: A Community Perspective
}

\author{
Sadhana Parajuli ${ }^{1}$, Prakash Gyawali ${ }^{2 *}$ and Narbikram Thapa ${ }^{2}$ \\ ${ }^{1}$ Ayurveda Campus and Teaching Hospital, Kirtipur, Nepal \\ ${ }^{2}$ Lumbini International Academy of Science and Technology, Nepal \\ *Corresponding Author: Sadhana Parajuli, Ayurveda Campus and Teaching \\ Hospital, Kirtipur, Nepal.
}

Received: February 22, 2021

Published: February 27, 2021

(C) All rights are reserved by Sadhana

Parajuli., et al.

\begin{abstract}
The study aims to assess the effects of air pollution in public health and socioeconomic situation in Chabahil, Kathmandu Metropolitan City. Air pollution has become the serious problem in the Kathmandu Metropolitan city. The air pollution has caused serious allergic problems in public health due to dust and carbanmonooxide emission. In the study reveal that the nasal congestions (58\%), sneezing (69\%), cough (75\%), hyperacidity (64\%), eye itching (64\%) etc. among the local people in the area. Similarly, non-allergic cases have also been reported due to air pollution. There has been found negative trend of air pollution level as compared to previous one in the study areas due to high carbon gas emission, dust and poor environmental sanitation etc. The overall changes in air pollution level have found significantly difference from 2.83 to 9.16 out of ten. The mean score difference is 6.33 during before and after situation mapping in the study areas. There has been found significant air pollution increased after ten years in the study areas.
\end{abstract}

Keywords: Air Pollution; Public Health; Respiratory Infection; Vehicular Emission; Environment

\section{Introduction}

Background

According to the 2011 census survey a total of 51,581 populations reported in Chabahil Ward No. 07 of Kathmandu Metropolitan City [1]. In the ward, there are $30 \mathrm{~km}$ of streets and 40,400 sq. m. of which are black topped [2]. The ward neighbors the Buddhist explorer objective of Bouddha on one side and the holiest Hindu sanctuary of Pashupatinath on the other. Antiquated landmarks like Chabahil's Ganesh sanctuary and Charumati Bihar help to offer character to the ward. Mitra Park, arranged at the point of convergence of the ward, uplifts its fascination. Despite the fact that actual framework like streets, drinking water, sewerage and phone is accessible in practically all pieces of the ward, they are need- ing upkeep as of now. Likewise, road lighting should be broadened. The ward is lined by Ward Nos. 6 and 8 in the east, Ward Nos. 4, 5 and 33 in the east, Ward Nos. 4 and 6 and Kapan VDC in the north, and Ward Nos. 8 and 9 in the south. The all out zone of the ward is 153.5 hectares. The street types have been introduced underneath (Table 1).

The condition of road seems to be not good quality as international standard due to poor planning, unplanned city, poor governance, poor maintenance etc. as observed. There has found more traffic jam in the areas that increases more time consuming to the travelers. There has found poor environmental sanitation and dust pollution around the study areas that caused acute respiratory infections, chronic obstetric pulmonary diseases (COPD), nasal congestion, eye infection etc. as experienced by the local people. 
Assessment of Air Pollution in Public Health and Socioeconomic Situation in Chabahil, Kathmandu Metropolitan City, Nepal: A Community Perspective

\begin{tabular}{|l|c|c|c|c|}
\hline \multirow{2}{*}{ Road Types } & \multirow{2}{*}{$\begin{array}{c}\text { Length } \\
(\mathbf{k m})\end{array}$} & & $\begin{array}{c}\text { Condition } \\
\mathbf{\%}\end{array}$ & \\
\cline { 3 - 5 } & & Good & Fair & Poor \\
\hline Blacktopped & 8.61 & 30 & 35 & 35 \\
\hline Gravel & 9.63 & 27 & 42 & 31 \\
\hline Dirt & 11.28 & 15 & 40 & 45 \\
\hline Track/Trail & 5.22 & 40 & 35 & 25 \\
\hline Brick Paved & 2.4 & 60 & 30 & 10 \\
\hline Stone Paved & 0.07 & 100 & & \\
\hline
\end{tabular}

Table 1: Road Type in Chabahil Area of Kathmandu Metropolitan City.

Source: http://kathmandu.gov.np/sites, 2017

\section{Condition of air pollution}

WHO (2014) stated that the air contamination has become a genuine natural concern and a general wellbeing risk in Kathmandu Valley. The convergence of particulate matter under 10 microns (PM10) in the Valley's surrounding air is now a few times higher than WHO more secure cutoff and Kathmandu is quite possibly the most contaminated urban communities in Asia concerning PM10 and PM 2.5 level [3]. However, MOEST (2005) has brought up that the degrees of vaporous pollutatns like oxides of nitrogen, oxides of sulfur, and ozone have not been discovered to be extremely high, they may increment later on with expanding mechanization. Besides, levels of harmful synthetic substances, for example, polyaromatic hydrocarbons (PAH) may likewise be high because of ignition in block ovens and diesel vehicles (MOEST, 2005) [4]. Yale University (2014) has called attention to that Nepal positioned second last after Bangladesh regarding air quality and its impact to human wellbeing [5]. World Bank (2012) expressed that Nepal is the quickest urbanizing country in South Asia and Kathmandu Valley is the quickest developing metropolitan region in the area (World Bank, 2012) [6]. As indicated by CBS (2011), the valley has noticed quick urbanization and populace development over the most recent couple of many years. The yearly populace development rate is $4.3 \%$ in the Valley and the yearly mechanization rate is $12 \%$ [7]. The Kathmandu valley is particularly powerless against air contamination because of random urbanization, quick mechanization, valley driven industrialization and its geology.

Citation: Sadhana Parajuli., et al. "Assessment of Air Pollution in Public Health and Socioeconomic Situation in Chabahil, Kathmandu Metropolitan City, Nepal: A Community Perspective". Acta Scientific Microbiology 4.2 (2021): 191-198. 


\section{Aim and Objectives}

The aim of the exploration is to survey the impacts of air contamination in general wellbeing and socioeconomic circumstance in Chabahil, Kathmandu Metropolitan City.

The following objectives have been set:

- To survey the effect of air contamination in general wellbeing zeroing in on the Chabahil zone of Kathmandu Metropolitan City, Kathmandu Area, Nepal.

- To analyze the air pollution level and its negative impacts on health and socio-economic status of the local people etc. in the study areas.

\section{Methodology}

The participatory methodologies and strategies were utilized during the investigation. The key source's meeting, members' perception, scores positioning, joy planning, and so forth techniques were utilized during the data assortment. The study was on the base of primary and secondary source of data. For the analysis of data, descriptive statistic like frequency distribution and per cent was used in this study.

\section{Results and Discussion}

\section{Effects of air pollution}

Spengler and Dockery, (1981) stated that the air pollution reduce the lung capacity in human being. The second component by which these respond is obstructive or meddling in nature without substance response. The more slender particulate saved in human lung meddles with typical capacities and causes lung illnesses or vague practical changes like asthma, pulse, ENT (eye, nose and throat), weariness, gastrointestinal infections, bronchitis or decrease of lung limits and disease In the event that there is a compound response of the material, it might achieve silicosis and pneumoconiosis. In the event that it contains things like hydrocarbons, and so forth, it might achieve lethal infections like malignancy. Particulate by covering the leaves' surfaces and stopping the stomata diminishes the assimilation of $\mathrm{CO}_{2}$ from the climate, the intensity of daylight and consequently smothers the photosynthesis and development of plants It additionally decreases perceivability by assimilation and dissipating by strong and fluid beads. Absolute openness to a person to a particular toxin is dictated by the centralization of pollutant and the length of its openness Particulate by covering the leaves' surfaces and stopping the stomata decreases the retention of $\mathrm{CO}_{2}$ from the environment, the power of daylight and in this way stifles the photosynthesis and development of plants [9]. TERI (1995) has contended that the openness to indoor and open air quality is diverse in light of the fact that they generally change with time and diurnal example TERI (1995) [10]. Anon (1997) called attention to that the wellbeing status and the openness level of a regular populace have closeness regarding living space, drinking water source, indoor microclimate, homegrown fuel utilization, development design, by and large expectation for everyday comforts, an overall feeling of wellbeing and cleanliness proficiency and connection with territory and working environment [11]. Certain airborne particulates like dust, contagious spores, house dust bug and creature dander [12] upon inward breath cause certain hypersensitive response including the respiratory frameworks like unfavorably susceptible rhinitis, point destructions and asthma $[13,14]$. Auxiliary photolytic responses in the air with natural parts and oxides of nitrogen and sulfur further has builds the PAH fixation [15] These are of checked ecological worry because of air contamination as a few of them are either known to be cancercausing agents or are suspected cancer-causing agents and mutagens [16]. Openness to SPM is likewise a similarly genuine danger to wellbeing. Inhalable SPM, especially under $10 \mathrm{~lm}$ in size, can go through the normal defensive component of the human respiratory framework. The littlest particulate ( $2 \mathrm{~lm}$ or less), which are coming principally from diesel, represent a lot more serious danger in light of their more noteworthy capacity to go through the human respiratory framework and stick to the internal tissue of the lung. It has been accounted for that in excess of 2,000 unexpected losses happened in Quetta in 2004 because of SPM. SPM incorporates all air-borne particles in the size scope of 0.5-100 lm. The genuine wellbeing harm brought about by dust particles relies on its tendency and creation [17]. The impacts of SPM are credited to mellow eye aggravation mortality (David 1995). Vehicle depletes and certain mechanical toxins contain NO2, which brought about by photochemical response produce 03 and influence unfavorably susceptible asthmatics by expanding hypersensitive reactions [18]. Essentially, $\mathrm{SO}_{2}, \mathrm{NO}$, particulate matter and corrosive vaporizers influence pneumonic capacity and cause aggravation of bronchial mucous (Giuseppe., et al. 1993; Karen and Michak, 1991). It has been seen from a few examinations that air contamination assumes a significant part in the beginning and expansion of hypersensitive 
Assessment of Air Pollution in Public Health and Socioeconomic Situation in Chabahil, Kathmandu Metropolitan City, Nepal: A Community Perspective

issue and it is depicted as a sickness of socialized society [19]. The greater part of the created western nations have received 25 and $1.5 \mathrm{lg} / \mathrm{dL}$ as far as possible for blood Pb levels in grown-ups and youngsters, individually (Neelman, 1993). Considering poisonousness at all levels, alternatives have been proposed to receive $10 \mathrm{lg} /$ $\mathrm{dL}$ as the blood $\mathrm{Pb}$ limit for everybody [20].

\section{Building structures}

In the study areas there have been found different types of building structures that include clay mortar, clay mortar and plaster, cement mortar, RCC frame etc. Many building has not found good condition except RCC frame due to poor quality of construction materials, poor designs and not yet properly repaired and maintenance (Table 2).

\begin{tabular}{|l|c|c|c|c|}
\hline \multirow{2}{*}{$\begin{array}{c}\text { Building } \\
\text { Structure }\end{array}$} & Percentage & & $\begin{array}{c}\text { Condition } \\
\text { \% }\end{array}$ & \\
\cline { 2 - 5 } & 2 & 40 & 40 & 20 \\
\hline Clay Mortar & Good & Fair & Poor \\
\hline $\begin{array}{l}\text { Clay Mortar } \\
\text { and Plaster }\end{array}$ & 25 & 50 & 35 & 15 \\
\hline $\begin{array}{l}\text { Cement } \\
\text { Mortar }\end{array}$ & 40 & 85 & 15 & - \\
\hline RCC Frame & 30 & 80 & 20 & - \\
\hline Other & - & - & - & - \\
\hline
\end{tabular}

Table 2: Building Structure in Chabahil Area of Kathmandu Metropolitan City.

Source: http://kathmandu.gov.np/sites, 2017.

Impact of air pollution on public health

The air pollution has caused serious allergic problems in public health due to dust and carbanmonooxide emission. There have been reported nasal congestions (58\%), sneezing (69\%), cough (75\%), hyperacidity (64\%), eye itching (64\%) etc among the local people. Similarly, non-allergic cases have also been reported due to air pollution as experienced by respondents (Table 3).

Sources of Principal pollutants in outdoor and indoor pollution

There are many sources for the air pollution which causes the problem in the public health's and environment. There have been

\begin{tabular}{|l|c|c|c|c|}
\hline Complaints & $\begin{array}{c}\text { Total no } \\
\text { of cases }\end{array}$ & Condition & $\begin{array}{c}\text { No of } \\
\text { persons }\end{array}$ & Percent \\
\hline $\begin{array}{l}\text { Nasal } \\
\text { congestion }\end{array}$ & 12 & $\begin{array}{c}\text { Allergic } \\
\text { Non-Allergic }\end{array}$ & 7 & 58 \\
\hline Sneezing & 13 & $\begin{array}{c}\text { Allergic } \\
\text { Non-Allergic }\end{array}$ & 4 & 42 \\
\hline Cough & 12 & $\begin{array}{c}\text { Allergic } \\
\text { Non-Allergic }\end{array}$ & 3 & 31 \\
\hline Hyperacidity & 11 & $\begin{array}{c}\text { Allergic } \\
\text { Non-Allergic }\end{array}$ & 7 & 75 \\
\hline Eye itching & 11 & $\begin{array}{c}\text { Allergic } \\
\text { Non-Allergic }\end{array}$ & 7 & 64 \\
\hline
\end{tabular}

Table 3: Estimation of Allergy symptom. Source: Focus Group Discussion, January, 2019.

identified the predominantly outdoor and indoor sources of pollutants that cause problems in the public health. The air pollution has become the serious public health problems in Kathmandu Valley particularly in the study areas as well. Some of the major sources and pollutants are presented below (Table 4).

\begin{tabular}{|l|c|}
\hline \multicolumn{1}{|c|}{ Principal Pollutants } & Sources \\
\cline { 2 - 2 } & Predominantly outdoor \\
\hline Sulphur dioxide and Particles & Fuel Combustion, Smelters \\
\hline Ozone & Photochemical reactions \\
\hline Pollens & Trees, grass, weeds, plants \\
\hline Lead, Manganese & Automobiles \\
\hline Lead, Cadmium & Industrial emissions \\
\hline $\begin{array}{l}\text { Volatile organic } \\
\text { Pompounds, } \\
\text { Aromatic hydrocarbons }\end{array}$ & $\begin{array}{l}\text { Petrochemical solvents, } \\
\text { vaporization of unburned } \\
\text { fuels }\end{array}$ \\
\hline $\begin{array}{l}\text { Nitrogen oxides and carbon } \\
\text { monoxide }\end{array}$ & $\begin{array}{c}\text { Both indoor and outdoor } \\
\text { Carbon dioxide }\end{array}$ \\
\hline
\end{tabular}




\begin{tabular}{|c|c|}
\hline Particles & $\begin{array}{c}\text { Environmental tobacco } \\
\text { smoke, resuspension, } \\
\text { condensation of vapors and } \\
\text { combustion products }\end{array}$ \\
\hline Water vapor & $\begin{array}{c}\text { Biologic activity, } \\
\text { combustion, evaporation }\end{array}$ \\
\hline Volatile organic compounds & $\begin{array}{c}\text { Volatilization, fuel burning, } \\
\text { paint, metabolic action, } \\
\text { pesticides, insecticides, } \\
\text { fungicides }\end{array}$ \\
\hline \multirow[t]{2}{*}{ Spores } & Fungi, moulds \\
\hline & Predominantly indoor \\
\hline Radon & $\begin{array}{l}\text { Soil, building construction } \\
\text { materials, water }\end{array}$ \\
\hline Formaldehyde & $\begin{array}{l}\text { Insulation, furnishing, } \\
\text { environmental tobacco } \\
\text { smoke }\end{array}$ \\
\hline Asbestos & Fire-retardant, insulation \\
\hline Ammonia & $\begin{array}{l}\text { Cleaning products, } \\
\text { metabolic activity }\end{array}$ \\
\hline $\begin{array}{l}\text { Polycyclic aromatic } \\
\text { hydrocarbons, arsenic, } \\
\text { nicotine, acrolein }\end{array}$ & $\begin{array}{c}\text { Environmental tobacco } \\
\text { smoke }\end{array}$ \\
\hline Volatile organic compounds & $\begin{array}{l}\text { Adhesives, solvents, } \\
\text { cooking, cosmetics }\end{array}$ \\
\hline Mercury & $\begin{array}{c}\text { Fungicides, paints, spills } \\
\text { or breakages of mercury } \\
\text { containing products }\end{array}$ \\
\hline Aerosols & $\begin{array}{l}\text { Consumer products, house } \\
\text { dust }\end{array}$ \\
\hline Allergens & $\begin{array}{l}\text { Consumer products, house } \\
\text { dust }\end{array}$ \\
\hline Viable organisms & Infections \\
\hline
\end{tabular}

Table 4: Principal pollutants and sources of outdoor and indoor pollution.

Source: adapted from WHO, 2000b.

\section{Before and now situation of local people about air pollution}

The score positioning device was utilized with the cooperation of local area women and men respondents to gauge the when circumstance planning of air contamination level in the study regions. There has been found negative trend of air pollution level as compared to previous one in the study areas due to high carbon gas emission, dust and poor environmental sanitation etc. (Table 5). The overall changes in air pollution level have found significantly difference from 2.83 to 9.16 out of ten. The mean score difference is 6.33 during before and after situation mapping in the study areas. There has been found significant air pollution increased after ten years in the study areas due to increased numbers of vehicles, poor environmental sanitation, poor governance, poor monitoring etc.

An aggregate of 10 seeds of bean (thought to be 100\%) were given to the respondents to quantify the progressions over the time of ten years when contrasted with the past one. The focus group conversation was utilized that included women and men individuals from nearby gatherings in the scoring exercise. Each gathering individuals were permitted to take an interest in the conversation prior to scoring in the previously and now circumstance planning. It was noticed that the higher the score more prominent the presentation during the score positioning by the respondents. The people group insight was map out dependent on the judgment of the respondents. This was estimated in relative terms.

\begin{tabular}{|l|c|c|c|c|}
\hline Parameters & $\begin{array}{c}\text { Before } \\
\mathbf{2 0 0 9} \\
\text { January }\end{array}$ & $\begin{array}{c}\text { Now } \\
\mathbf{2 0 1 9} \\
\text { January }\end{array}$ & Difference & Impact \\
\hline $\begin{array}{l}\text { Acute } \\
\text { Respiratory } \\
\text { Infection }\end{array}$ & 3 & 9 & 6 & $\begin{array}{c}\text { Increase } \\
\text { pneumonia, } \\
\text { cough, asthma }\end{array}$ \\
\hline $\begin{array}{l}\text { Cardiovascu- } \\
\text { lar Diseases }\end{array}$ & 2 & 10 & 8 & $\begin{array}{c}\text { Increasing heart } \\
\text { problem }\end{array}$ \\
\hline $\begin{array}{l}\text { Noise } \\
\text { pollution }\end{array}$ & 2 & 10 & 8 & $\begin{array}{c}\text { Increasing stress } \\
\text { level }\end{array}$ \\
\hline $\begin{array}{l}\text { Carbon } \\
\text { Emission }\end{array}$ & 3 & 8 & 5 & $\begin{array}{c}\text { Nasal congestion, } \\
\text { asthma etc. }\end{array}$ \\
\hline Dust pollution & 3 & 9 & 6 & $\begin{array}{c}\text { Cough, nasal } \\
\text { congestion }\end{array}$ \\
\hline Eye Itching & 4 & 9 & 5 & Eye infection \\
\hline Mean score & 2.83 & 9.16 & 6.33 & \\
\hline
\end{tabular}

Table 5: Perception Mapping of Before and After Situation of Air Pollution in Chabahil Area.

Source: Focus Group Discussion, January, 2019.

Perception mapping of local people about air pollution

At the point when we have got some information about the discernment towards the air contamination level in the investigation 
territories, the respondents have scored 150 (100\%) for unhappy. The investigation shows that the practically all respondents have discovered discontent with the low quality of air contamination. Individuals are truly getting disturbing and dealing with difficult issues from the grievous furthest reaches of air contamination because of emanation of carbanmonooxide from vehicles, dust contamination and poor ecological sterilization and so forth The nearby individuals have asked to government to keep up the air contamination at typical standard level. The bliss planning apparatus was utilized to outline the view of the neighborhood individuals towards air contamination level in the investigation zones (Table $6)$.

An aggregate of 10 corn seeds expected as $100 \%$ were given to every respondent. The people group insight was delineated dependent on their immediate perception, experience and best judgment of the respondents. This was estimated in relative terms. The recurrence addresses the scoring of the respondents as basic, handily comprehended and versatile boundaries at neighborhood level.

\begin{tabular}{|l|c|c|}
\hline \multicolumn{1}{|c|}{ Parameters } & Frequency & Percentage \\
\hline Very Happy & 00 & 0 \\
\hline Happy & 00 & 0 \\
\hline Unhappy & 150 & 100 \\
\hline Don't Know & 00 & 0 \\
\hline No Response & 00 & 0 \\
\hline Total & 150 & 100 \\
\hline
\end{tabular}

Table 6: Perception mapping for Air pollution. Source: Local Member of Chabahil Area, January 2019.

\section{Migation measures for urban air pollution}

The improvement of the socio-natural conditions and decreases of wellbeing trouble inside Kathmandu, Chabahil city can be contended on the general wellbeing grounds as well as based on the drawn out financial flourishing of the city. The contamination issue has arrived at a particularly disturbing level that no delicate alternative would assist with rescuing the circumstance. A solid willed government-sponsored by ready people can address the issue of expanding air contamination in a powerful manner [21]. An assortment of issues needs an assortment of arrangements. In any case, it is similarly essential to pressure air quality checking just as the investigation on the wellbeing impacts. A model for the digestion has been made and is provided by a first-request dynamic capacity [22]. The observational model for anticipating long haul normal SPM focus can be used for dissecting the impacts of different traffic decrease methodologies. To make an essential arrangement for the air quality administration (AQM) program, a discussion with a wide cluster of interests is required. Epidemiological information from clinics and different organizations are to be considered as the beginning stage for recognizing linkage between surrounding air quality levels and persistent or intense medical issues. Some objective gatherings (for example traffic constables, side of the road peddlers, and so on) and non target gatherings, (for example, individuals living in pieces of the city where gridlock is less or provincial individuals) were chosen on an irregular premise and checked. This period of information assortment comprised the basic stage in building up a significant AQM program. The advantages of decreasing air contamination are to be anticipated. AQM program gets effective in the event that it incorporates the appraisal to legitimize the important uses. There are many impacting apparatuses which are to be utilized for full consistence of natural objective, for example clean air. Indicating is vital for choosing the alternative for moderating air contamination. Albeit the fundamental wellspring of air contamination is the vehicle area, the business additionally assumes a key part. For moderating air contamination in the city of Kathmandu, restricting emanations from both fixed (industry) and portable (transport) will be required. A likely arrangement is to move stage savvy the medium and low contaminating ventures in a mechanical territory outside as far as possible. Ventures ought to be urged to switch over to cleaner fills like flammable gas. Energy preservation choices are to be supported. Enterprises ought to be urged to create techniques to draw from elective fuel source. Inner control guideline ought to be made required for every modern area. Choices for lessening air contamination from portable sources incorporate supplanting old vehicles, keeping up being used vehicles all the more adequately, utilizing elective cleaner powers, reformulating energizes, improving traffic the executives, growing mass travel frameworks and improving the street limit [23]. The majority of the vehicles are diesel-driven and SPM fixation was additionally discovered to be high. The expense of reformulating diesel oil is high, yet it ought to be a high need to decrease SPM. Fluid petrol gas (LPG) and compacted petroleum gas (CNG) ought to be presented in a staged way. Exhaust systems that lessen exhaust 
outflow and discharge guidelines of vehicles ought to be authorized carefully. Kathmandu grew up so randomly that improving the foundation is a calculated and monetary bad dream. By keeping the principle blood vessel street sans pothole, pathways liberated from vendors and augmenting the streets any place conceivable ought to be given main concern. Improved practices for overseeing traffic can decrease clog essentially. An improved arrangement can incorporate impetuses and disincentives like confining utilization of fundamental conduits, empowering vehicle pooling, giving motivators to utilize public vehicle, improving public travel framework or setting up new ones, burdening vehicles entering as far as possible, forcing more extreme leaving expenses, and forcing a natural assessment on cars. Traffic the executives and street enhancements ought to be given high need to lessen air contamination in Kathmandu. On the whole these recommendations, medical advantages ought to be incorporated to demonstrate support for endowments. The quantity of trees per square kilometer was discovered to be 2 while preferably, it ought to be 100 . Along these lines, prompt advances ought to be taken to expand the quantity of trees after an appropriate stock of all species in Kathmandu. Open spaces and stops ( 2 square $\mathrm{ft}$ for every individual) ought not be infringed upon, and legitimate eco-planning of these territories ought to be done right away.

\section{Conclusion}

Kathmandu is discovered to be quite possibly the most contaminated urban areas in Nepal. The investigation shows that the situation with air contamination is discovered to be basic and has arrived at a compromising level. Air contamination appraisal and effect on human wellbeing emerging in the zone showed an undeniable degree of engraving score. Unexpected passing because of SPM is accounted for to be high and the kids are the most noticeably awful influenced bunches in Kathmandu. An essential arrangement has been proposed and the relief measures recommended to control the metropolitan air contamination would improve the circumstance whenever executed appropriately. There is no very much characterized rule for the appraisal of the situation with metropolitan air contamination and its effect on general wellbeing. No orderly investigations have been accounted for to assess the situation with metropolitan air contamination and its effect in the urban areas of Nepal and there will be huge ramifications of the proposed approach and the future use of such evaluations is to deal with the metropolitan air contamination issue. Critical move should be made to make the city's air breathable and diminish the negative effect on general wellbeing, economy and climate. The air pollution level of Kathmandu Valley has been affected by brick kilns of Bihar and Uttarpradesh of India as well. There is a need of lobbying and advocacy to influence policy and practice in neighboring country also.

\section{Bibliography}

1. CBS. "National population and Housing Census 2011 (National Report)". Kathmandu: Central Bureau of Statistics (2012).

2. http://kathmandu.gov.np/sites

3. Urban air quality and its management in Asia: Status Report, Presented at the Regional Dialogue of Air Quality Management Initiatives and Programs in Asia. 12 October. Bangkok, Thailand (2006).

4. Monthly Air Quality Monitoring Datasheet, Ministry of Science, Technology and Environment.

5. Yale University. Environmental Performance Index (2014).

6. Urban Growth and Spatial Transition: An Initial Assessment Nepal, World Bank (2012).

7. National population and Housing Census (National Report). Kathmandu: Central Bureau of Statistics (2011).

8. Brimblecombe P. “The Big Smoke”. London: Methuen (1987).

9. Spengler J D and Dockery D W. "Personal exposure to respirable particulates and sulphates". Journal of the Air Pollution Control Association 31 (1981): 153-159.

10. TERI: Health Risk and Cost Effective Interventions for Indoor Air Pollution -A Report, Tata Energy Research Institute, New Delhi (1995).

11. Anon. Monitoring of Human Exposure to Air Pollution in Highly Industrial Area, Central Pollution Control Board, New Delhi (1997a).

12. Tilak J. "Mites and mite allergy as risk factor for asthma”. Annals of Allergy 63 (1989): 392-397.

13. Arruda LK., et al. "Selective expression of a major allergen and cytotoxin aspergillus fumigates". Journal of Immunology 149 (1992): 3554-3559. 
14. Fernandes L. "Anacardium occidentals pollen allergy in patients with allergic bronchial asthma". The Journal of Allergy and Clinical Immunology 95 (1995): 501-504.

15. Schoential P. in: E. Clar (ed), Polycyclic Hydrocarbons, Academic Press, New York 1 (1964): 487-496.

16. Andrews AW., et al. "The relationship between carcinogenicity and mutagenicity of polynuclear hydrocarbons". Mutation Research 51 (1978): 311-318.

17. Binder R E., et al. "Importance of the indoor environment in the air pollution exposure". Archives of Environmental Health 31 (1976): 277-279.

18. Steinberg JJ., et al. "The pathobiology of ozone-including damage". Archives of Environmental Health 46 (1991): 80-87.

19. Bonai S., et al. "Genetic and environmental factors in changing the incidence of allergy". Journal of Allergy 49 (1994): 6-14.

20. Boeck R L. "Lead poisoning in children". Annals of Chemistry 58 (1980): 274-A.

21. Shukla N., et al. "Exposure assessment to particulate matter in the middle class sub-population of East Delhi, Energy". Environmental Monitoring 13 (1997) 69-76.

22. McEnvoy J E. "Lead modeling -a decision making tool”. Science of the Total Environment 16 (1990): 231-237.

23. Calvert JG., et al. "Achieving acceptable air quality: Some reflections on controlling vehicle emissions". Science 261 (1993): 3745.

\section{Assets from publication with us}

- Prompt Acknowledgement after receiving the article

- Thorough Double blinded peer review

- Rapid Publication

- Issue of Publication Certificate

- High visibility of your Published work

Website: $w$ ww.actascientific.com/

Submit Article: www.actascientific.com/submission.php

Email us: editor@actascientific.com

Contact us: +919182824667

Citation: Sadhana Parajuli., et al. "Assessment of Air Pollution in Public Health and Socioeconomic Situation in Chabahil, Kathmandu Metropolitan City, Nepal: A Community Perspective". Acta Scientific Microbiology 4.2 (2021): 191-198. 